\title{
Effect of Increased Slope on Corn Productivity and Nitrogen Losses in Runoff Water
}

Min Woong Jung ${ }^{1}$, Wan Bang Yook ${ }^{2}$ and Ki Choon Choi ${ }^{1}$

\section{경사도 증가가 옥수수의 생산성 및 유거수 중의 $\mathrm{N}$ 의 유실에 미치는 영향}

정민웅 ${ }^{1}$. 육완방 $^{2}$. 최기춘 ${ }^{1}$

\begin{abstract}
요 약
본 연구는 우분액비의 시용이 경사도를 달리한 사료용 옥수수 재배지에서 옥수수의 생산성 및 유 거수 중의 $\mathrm{N}$ 의 유실에 미치는 영향을 조사하기 위하여, 건국대학교 축산대학 사료작물 시험포 내 설 치된 Erosion apparatuses (가로 $0.33 \mathrm{~m}$, 세로 $3 \mathrm{~m}$, 깊이 $0.4 \mathrm{~m}$ )를 이용하여 수행하였다. 시험구의 경사도 는 $0 \%, 8.75 \%, 17.50 \%$ 로 하였으며, 우분액비는 6 개월 이상 부숙된 것으로 질소 기준 $200 \mathrm{~kg} / \mathrm{ha}$ 시용하 였다. 옥수수의 건물생산성과 사료가치는 경사도에 의해 영향을 받았으며, $17.50 \%$ 경사지의 건물생산 성은 $0 \%$ 경사지의 건물생산성에 비해 유의적인 감소를 보였다 $(\mathrm{P}<0.05)$. 유거수 중의 평균 $\mathrm{NO}_{3}^{-}-\mathrm{N}$ 과 $\mathrm{NH}_{4}{ }^{+} \mathrm{N}$ 의 농도는 경사가 높아질수록 유의적으로 증가하였다 $(\mathrm{P}<0.05)$. 이상의 결과에서 보는 바와 같 이 우분액비를 시용하여 사료용 옥수수를 재배할 경우, 경사도가 증가할수록 그리고 집중호우가 발생 할 경우에 유거수 중의 양분 유실량은 증가가 예상되기 때문에 경사도가 심한 지역에서 옥수수를 재 배할 때에는 양분유실에 따른 수질오염을 고려하여 사료작물 재배 방법이 모색되어야 한다.
\end{abstract}

(Key words : Cattle slurry, Corn, Nutritive value, Slope, Soil fertility, Runoff)

\section{INTRODUCTION}

The intensification of livestock production in Korea over the past 30 years has led to the production of high quantities of livestock manure (LM). An estimated 41 million tones of LM are collected, annually, within Korean farm building and yields. Environmental contamination can occur when application of LM to the topsoil is in excess of crop utilization potential, or is done under poor management conditions causing nutrient losses due to environmental factors such as soil erosion or surface runoff during rainfall (Smith et al., 2001a Smith et al., 2001b; Ramos et al., 2006, Vadas et al, 2007; Allen and Mallarino, 2008). However, LM is effective in

\footnotetext{
${ }^{1}$ 농촌진흥청 국립축산과학원 (National Livestock Research Institute, Rural Development Administration, Seonghwan-Eup, Cheonan-Si, Chungnam,, Korea)

${ }^{2}$ 건국대학교 동물생명과학대학 (Department of Animal Sciences Environment, College of Animal Husbandry, Kon-Kuk University, Seoul 143-701, Korea )

Corresponding author: Dr. Ki Choon Choi, National Livestock Research Institute, Rural Development Administration, Seonghwan-Eup, Cheonan-Si, Chungnam, 330-801, Korea. Tel: +82-41-580-6752, Fax: +82-41-580-6779, E-mail:choiwh@korea.kr.
} 
the improvement of the physical and chemical properties of the soil for plant growth and the increase in its organic matter content (Gilley et al., 1999; Leon-Gonzalez et al., 2000; Nyamangara et al., 2001, Lazcano et al. 2008).

Thus, the efficient utilization of LM is also important in the aspect of environmental preservation (Vadas et al, 2007). Without careful management, large quantities of LM represent an important potential source of losses of nutrients to ground and surface water as a result of incidental losses in surface and sub-surface flow, directly following surface application or indirectly following enrichment of soil nutrients (Vadas et al, 2007; Allen and Mallarino, 2008; Sonneveld et al, 2008).

Avoiding losses of soil nutrients shall benefit the wider environment and can contribute to more efficient use of nutrients within the farming system, which are most likely to occur in surface runoff through the transport of nutrients resulting from long-term over-fertilization and/or excessive application of LM.

Especially, surface runoff during rainfall can cause significant pollution following the application of LM to the land (Sherwood and Fanning, 1981; Hubbard et al., 1987; Allen and Mallarino, 2008). For example, increasing concentrations of $\mathrm{N}$ in surface runoff may contribute to eutrophication of lakes and rivers (Wenchuan et al., 2001). Therefore, it is essential to examine $\mathrm{N}$ losses from the lands receiving cattle slurry (CS) in various environmental conditions because those losses from agricultural fields via erosion and runoff occur. Although some researchers have attempted many times to control $\mathrm{N}$ losses from fields receiving LM (Smith et al., 2001a Smith et al., 2001b Vadas et al, 2007; Allen and Mallarino, 2008; Sonneveld et al. 2008), studies related with migration of $\mathrm{N}$ from the soil in a sloping land under Korean soil and climate conditions have yet to be conducted.

Most of crop cultivation lands in Korea, except paddy fields, lie on a slope and the significant precipitation experienced during a normal summer season leads to runoff of nutrients rather than their leaching into the subsurface. Haan et al.(1994) suggested that the degree and length of slope influenced runoff rates. $\mathrm{N}$ runoff from agricultural ecosystems is one of the major environmental problems related to agricultural plant production; furthermore, the amount of $\mathrm{N}$ runoff through natural soil is seldom predicted. Interestingly, some researches indicate that the several days following LM application, particularly where significant rainfall occurs soon after application, represents a high risk period (Jarvis et al., 1987; Edwards and Daniel, 1993).

In an attempt, to investigate the CS utilization as part of an environmental preservation recycling system for forage crop cultivation, we examine the effects of application of CS taking into account the degree of land slope on corn yields and soil fertilities, and nitrogen $(\mathrm{N})$ losses via runoff.

\section{MATERIALS AND METHODS}

\section{Experimental site and soil}

This study was carried out for two years at an experimental field of the College of Animal 
Husbandry, Konkuk University, Seoul, Korea. During the experimental period (May to August), the mean precipitation and temperature are 239 $\mathrm{mm}, 21.5^{\circ} \mathrm{C}$ in 2003 and $153 \mathrm{~mm}, 24.2^{\circ} \mathrm{C}$ in 2004, respectively (Fig. 1). Soil type was classified as sandy loam soil. The characteristics of the soil are shown in Table 1.

\section{Experimental design}

The field experiments were conducted on steel-made erosion apparatuses for two years. These were constructed with $0.33 \mathrm{~m}$ width $3 \mathrm{~m}$ length and $0.4 \mathrm{~m}$ height. The field experiments were conducted on steel-made erosion apparatuses at Konkuk University, from 2003 to 2004. Each treatment was replicated three times. All plots were consisted of various degree of slope, such as $0 \%, 8.75 \%$ and $17.50 \%$. CS was produced by Korean native cattle fed with grass silage and rice straw. CS was consisted of the mixture of feces and urine of cattle and manufactured by the fermentation for 6 months in natural condition. Characteristics of CS used in this study are shown in Table 2. Application rates were calculated in total nitrogen contents. CS was applied at $200 \mathrm{~kg} \mathrm{~N}^{-1}$ year $^{-1}$ on each plot at 10 days before seeding and $100 \mathrm{~kg} \mathrm{~N} \mathrm{ha}{ }^{-1}$ year $^{-1}$ of urea was applied in the middle of growing. The fertilizer and CS were applied in two equal dressings.
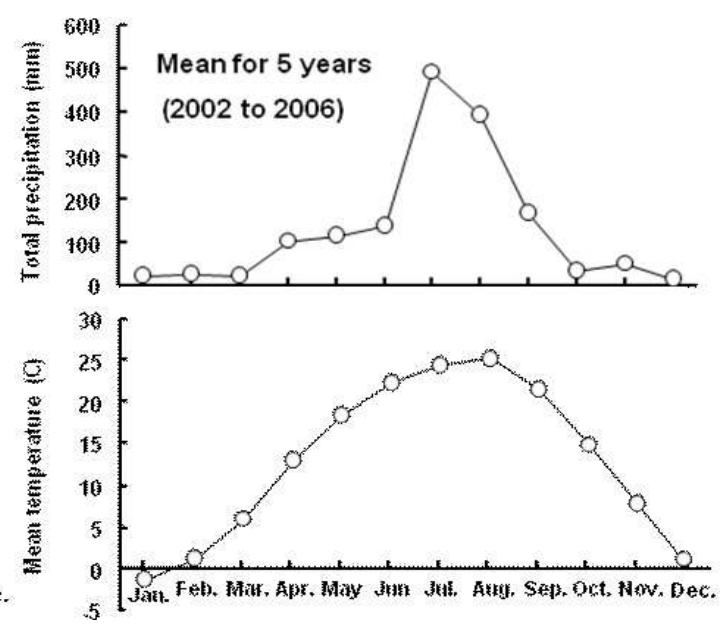

Fig. 1. Meteriological information during the experimental periods.

Table 1. Chemical characteristics of the soil collected at control treatment before and after each experiments

\begin{tabular}{cccccccccc}
\hline & $\mathrm{pH}$ & $\mathrm{OM}^{1)}$ & $\mathrm{Av} . \mathrm{P}_{2} \mathrm{O}_{5}{ }^{2)}$ & \multirow{2}{*}{$\mathrm{T}^{3} \mathrm{~N}^{3)}$} & \multicolumn{4}{c}{$\begin{array}{c}\text { Exchangeable cations } \\
\left(\mathrm{cmol}^{+} / \mathrm{kg}\right)\end{array}$} \\
\cline { 7 - 10 } & $\left(1: 5 \mathrm{H}_{2} \mathrm{O}\right)$ & $(\%)$ & $(\mathrm{mg} / \mathrm{kg})$ & $(\%)$ & $\mathrm{Mg}$ & $\mathrm{Ca}$ & $\mathrm{K}$ & $\mathrm{Na}$ \\
\hline \hline Before & 5.66 & 0.46 & 35.04 & 0.05 & 1.98 & 2.54 & 0.12 & 0.05 \\
After & 6.10 & 0.77 & 51.48 & 0.08 & 2.81 & 7.20 & 0.14 & 0.05 \\
\hline
\end{tabular}

${ }^{1)}$ Organic matter, ${ }^{2)}$ Average $\mathrm{P}_{2} \mathrm{O}_{5},{ }^{3)}$ Total nitrogen 
Table 2. Characteristics of cattle slurry used in this experiment.

\begin{tabular}{cccccc}
\hline Item & $\begin{array}{c}\text { Total nitrogen } \\
(\%)\end{array}$ & $\begin{array}{c}\mathrm{P}_{2} \mathrm{O}_{5} \\
(\%)\end{array}$ & $\begin{array}{c}\mathrm{K}_{2} \mathrm{O} \\
(\%)\end{array}$ & $\begin{array}{l}\mathrm{NH}_{4}-\mathrm{N} \\
(\mathrm{ug} / \mathrm{ml})\end{array}$ & $\begin{array}{c}\mathrm{NO}_{3}-\mathrm{N} \\
(\mathrm{ug} / \mathrm{ml})\end{array}$ \\
\hline \hline Cattle slurry & $0.51 \sim 0.71$ & $0.126 \sim 0.132$ & $0.413 \sim 0.445$ & $3,972 \sim 4,021$ & $486 \sim 501$ \\
\hline
\end{tabular}

\section{Corn yields and feed value}

Corn 'Pioneer 3310' were sown at intervals of $20 \mathrm{~cm}$ with 2 grains in the early of May (May 1, 2003 and May 3, 2004). After the emergence, a corn, full of vitality, was utilized for the experiments. The sown corn were grown and survived well during the experimental period. Corn was harvested in the middle of August (August 20 in 2003 and August 26 in 2004). The field experiment was conducted in accordance with the Konkuk University Guide for the Use of Forage Crops. The samples were dried at $80^{\circ} \mathrm{C}$ for 2 days to examine the corn yields and ground to pass through a $1 \mathrm{~mm}$ sieve to analyze the nutritive values of corn. Nutritive values of corn were analyzed using the AOAC method (1990). Total digestible nutrients (TDN) content was calculated by modifying Jurgens's method.

\section{Analysis of soil properties}

To examine the soil properties, the soils were sampled randomly from the plots at a depth of 0 to $20 \mathrm{~cm}$ in control treatment before and after experiment. Soil samples were dried by ambient air in a shadow place at room temperature. After drying, the samples were ground to pass through at $1 \mathrm{~mm}$ sieve. Chemical properties of the soil were analyzed by the method of AOAC (1990).

\section{5. $\mathrm{NO}_{3}{ }^{-}-\mathrm{N}$ and $\mathrm{NH}_{4}{ }^{+}-\mathrm{N}$ analysis in runoff water}

Runoff water was gathered in $50 \sim 2,000 \mathrm{ml}$ of plastic bottles installed under each erosion apparatus. Before sampling, the water in each bottle was stirred vigorously to suspend any sediment at the bottom of the bottles. All representative samples was rapidly collected from plastic sampling bottles within regular intervals, immediately frozen in deep freezer and stored at $-20^{\circ} \mathrm{C}$ All samples were analyzed within 24 hours after collecting the sample. $\mathrm{NO}_{3}-\mathrm{N}$ and $\mathrm{NH}_{4}-\mathrm{N}$ concentrations were determined using a Flow Injection Analyser (FIAstar 5000, Foss Tecator, Sweden).

\section{Statistical analysis}

All statistical analyses were performed using SPSS/PC statistical program(Version 10.0 for Windows; SPSS, Inc., Chicago, IL, USA). All data were expressed as means \pm SE. Statistical analysis of the data was done by one-way analysis of variance (ANOVA) and Duncan's multiple comparison tests to identify differences between the groups, which is considered significant when $\mathrm{P}<0.05$.

\section{RESULTS}

\section{Dry matter (DM) yields of corn}


Fig. 2 shows the pattern of changes for DM yields of corn according to the degree of the slope for two years. Average DM yields significantly decreased as the degree of the slope increased $(\mathrm{P}<0.05)$. DM yields were higher in $8.75 \%$ of the slope when compared to $17.5 \%$ of the slope. But, there was not significantly difference between $8.75 \%$ and $17.5 \%$ of the slope.

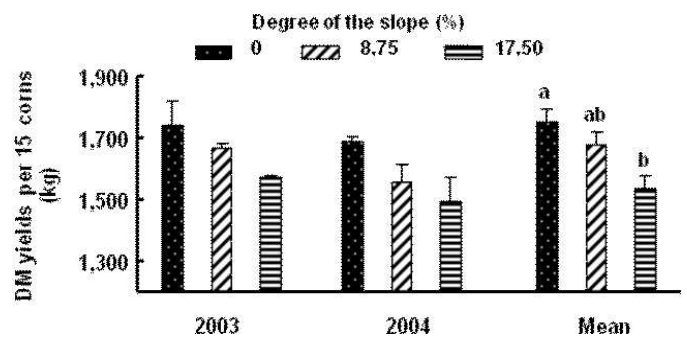

Fig. 2. Effect of cattle slurry application according to the degree of slope on dry matter (DM) yields of corn. The data represent the means $\pm S E$ of the three experiments. $a, b$ : Different letters within each slope represent significant differences $(\mathrm{P}<0.05)$.
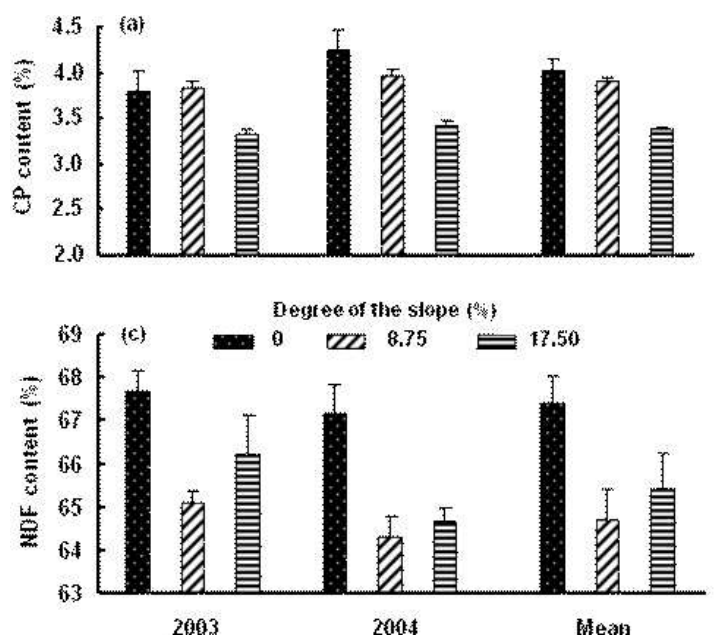

\section{Nutritive values}

To examine whether the changes of nutritive values (crude protein, CP (a) acid detergent fiber, $\operatorname{ADF}(b)$; neutral detergent fiber, NDF (c) in the degree of slope, nutritive values in whole plants were analyzed by AOAC methods. The contents of $\mathrm{CP}, \mathrm{ADF}$ and $\mathrm{NDF}$ were higher in $0 \%$ of the slope when compared to 8.75 and $17.5 \%$ of the slope (Fig. 3). However, there were not significant differences between the slopes. Total digestible nutrients (TDN) yields of corn decreased as the degree of the slope increased (Fig. 3 (d)) There was significantly different between $0 \%$ and $17.5 \%$ of the slope $(\mathrm{P}<0.05)$.

\section{3. $\mathrm{NO}_{3}{ }^{-}-\mathrm{N}$ and $\mathrm{NH}_{4}{ }^{+}-\mathrm{N}$ concentrations in runoff water}

This experiment was carried out to examine the effect of CS application on runoff pollution by the degree of slope. Surface runoff water
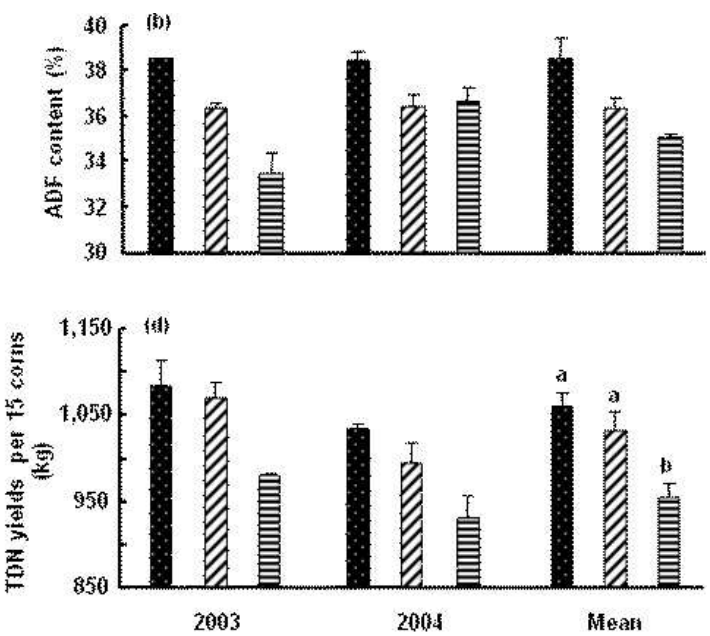

Fig. 3. Effect of cattle slurry application according to the degree of slope on nutritive values of corn. CP, Crude protein (a); ADF, Acid detergent fiber (b); NDF, Neutral detergent fiber (c); TDN, Total digestible nutrients (d). The data represent the means \pm SE of the three experiments. 
was collected in calibrated bottles and samples were taken during significant rainfall event for determination of total solids concentration. As shown in Fig. 4, $\mathrm{NO}_{3}{ }^{-} \mathrm{N}$ and $\mathrm{NH}_{4}{ }^{+}-\mathrm{N}$ concentrations significantly elevated by increasing the slope during the experimental period $(\mathrm{P}<0.05)$.

\section{Changes of the soil properties by CS application}

Changes of soil properties after the end of experiments showed in Table 1. Soil $\mathrm{pH}$ increased up to 6.10 by CS application. Organic matter, total nitrogen and phosphorus contents at the end of experiments were approximately 0.7 , 0.6 and 0.5 fold higher, respectively, than those in the soil before experiments. In addition, the exchangeable cations also highly increased by the application of CS.

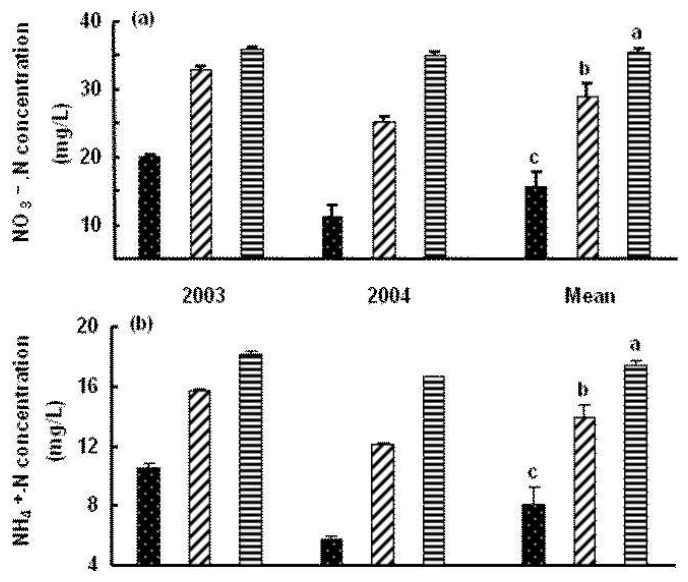

Fig. 4. Effects of cattle slurry application according to the degree of slope on total $\mathrm{NO}_{3}{ }^{-} \mathrm{N}$ (a) and $\mathrm{NH}_{4}-\mathrm{N}$ (b) concentrations in runoff water during the experimental period. The data represent the means $\pm S E$ of the three experiments. a, b, c: Different letters within each slope represent significant differences $(P<0.05)$.

\section{DISCUSSION}

The present study demonstrates that corn yields and soil properties, and concentrations of $\mathrm{NO}_{3}{ }^{-}-\mathrm{N}$ and $\mathrm{NH}_{4}{ }^{+} \mathrm{N}$ in surface runoff water following application of CS to corn field have a strong correlation with the slope of the land.

In this study, the effects of degree of the slope on the yields and nutritive values of corn from a corn field were examined using a tilting soil chamber. In general, much research has shown that the yields and nutritive value of forage crops were influenced by times, rates and method of cattle manure application, including the environmental condition during and after application upon crop lands (Lithourgidis et al. 2007; Butler and Muir, 2006; Adeli et al., 2005; Bakhsh et al., 2005; VanWieringen et al. 2005; Matsi et al. 2003; Newton et al. 2003; Phillips et al. 1981). As shown in our results, the yields and nutritive values of corn were also dramatically associated with the slope. This may have been caused by the direct relationship between nutrient losses and a large volume of runoff brought by heavy rainfall on the sloping land during the experimental period. The slopes are especially important in use of CS, because runoff is an important pathway for nutrient losses in soils. Based on CS application with increasing the degree of slope, it does appear that nutritive values of corn are reduced. In Korea, the losses of fertilizer properties mostly occur soon after application in late May, when corn is not growing. If managed properly, controlled CS application has the potential to improve corn yields by using more nutrients available to corn. 
According to our results, concentrations of $\mathrm{NO}_{3}{ }^{-}-\mathrm{N}$ and $\mathrm{NH}_{4}{ }^{+}-\mathrm{N}$ were significantly increased by increasing the slope. Researchers from many country have demonstrated that the slopes increase surface runoff(because soils have less space to store water), and significantly increase nitrogen losses as compared with the flate fields (Haan et al. 1994).

Based on optimum economic return, overapplication of CS fertilizer should be less profitable. It should be noted, however, that agricultural soils along the slope have significant nitrogen losses from the natural process of organic matter mineralization. If managed properly the relationship between CS application and the slope, CS has the potential to improve crop yields by using more nutrition materials available to crops. Smith et al. (2001a) and Smith et al. (2001b) also suggest that the application of organic manures, especially slurries, to arable soil susceptible to runoff shall only increase surface runoff and the loss of solids of $\mathrm{NH}_{4}$-N. Interestingly, a strong positive correlation is observed between the amount of rainfall within a 72-hour period after slurry application and DM response, and rainfall pattern after surface application of slurry could have a strong influence on subsequent $\mathrm{N}$-use efficiency (Miller et al. 2006; Long and Gracey, 1990). In this study, losses of $\mathrm{NO}_{3}{ }^{-} \mathrm{N}$ and $\mathrm{NH}_{4}{ }^{+}-\mathrm{N}$ via runoff following applications of CS to corn land were significantly affected by increase of slope. These losses were significantly elevated by increasing the slope during the experimental period.

The amount and pattern of nutrient losses are very similar to those of rainfall with the peak concentrations of nutrient losses via runoff during the experimental period corresponding to the peak amount of rainfall (data not shown). Owens et al. (1984) observed that all peak nitrate concentrations occur shortly after applications of fertilizer. Steffens (1991) also reports low nutrient losses via runoff due to precipitation, concluding that risk of pollution is greater from direct slurry runoff following application, particularly with slurries of low dry matter content.

Therefore, slurry runoff is carefully handled in aspect of environmental preservation, because $60 \sim 70 \%$ of annual rainfall $(1,100 \sim 1,400 \mathrm{~mm})$ of Korea occurs during the summer period (July to September). The concentrations of nitrogen losses via runoff have been caused by the heavier rainfall. Factors and mechanisms involved in the generation of surface runoff, following land application of animal manure (AM), are fully discussed in papers associated with $\mathrm{N}$ losses of AM (Smith et al., 2001a; Smith et al 2001b). Our results strongly suggest that runoff following applications of animal waste to the slopping grassland represents both a potential source of pollution of surface waters and nutrient losses for the crop. In addition, the chemical and physical properties in the soil at the end of the experiments were improved by CS application as compared to those in the soil before the experiments, although there have been some losses of fertilizer properties in the soils. As shown in our results, many researchers report that AM improves the chemical and physical properties of soils and increases their organic matter content (Freeze and Sommerfeldt, 1985; Campbell et al., 1986; Sommerfeldt et al., 1988; Eghball and Power, 1994). The results of 
our study show that the degree of slope and the rainfall intensity during the growing season of corn comprisethe major factors affecting corn productivity and nutrient losses from slopping land. Our data are also available to help many farmers using CS and pay for management approaches to prevent and to control nutrient losses from the slope to minimize the pollution of the surface and groundwater.

In conclusion, our findings suggest that longer term experiments covering several kinds of applied LM and weather conditions, and investigating runoff beyond treated areas are necessary and would give more quantitative information on environmentally friendly utilization of AM.

\section{REFERENCES}

1. Adeli, A., J.J. Varco, K.R. Sistani and D.E. Rowe. 2005. Effects of swine lagoon effluent relative to commercial fertilizer application on warm-season forage nutritive value. Agron. J. 97: 408-417.

2. Allen, B.L. and A.P. Mallarino. 2008. Effect of Liquid Swine Manure Rate, Incorporation, and timing of rainfall on phosphorus loss with surface runoff. J. Environ. Qual. 37:125-137.

3. AOAC. 1990. Official methods of analysis (15th ed.). Association of Official Analytical Chemisits, Washington, DC.

4. Bakhsh, A., R.S. Kanwar and D.L. Karlen. 2005. Effects of liquid swine manure applications on $\mathrm{NO}_{3}{ }^{-}-\mathrm{N}$ leaching losses to subsurface drainage water from loamy soils in Iowa. Agr. Ecosyst. Environ. 109:118-128.

5. Butler, T.J. and J.P. Muir. 2006. Dairy manure compost improves soil and increases tall wheatgrass yield. Agron. J. 98:1090-1096.

6. Campbell, C.M., M. Schnizer, J.W.B. Stewart, V.O. Biederbeck and F. Selles. 1986. Effects of manure, $\mathrm{P}$ fertilizer on properties of a Black Chemozem I southern Saskachewan. Can. J. Soil Sci. 66:601-613.

7. Edwards, D.R. and T.C. Daniel. 1993. Runoff quality impacts of swine manure applied to fescue plots. Transactions ASAE. 36:81-86.

8. Eghball, B. and J.F. Power. 1994. Beef cattle manure management. J. Soil Water Conserv. 49: 113-122.

9. Freeze, G.S. and T.G. Sommerfeldt. 1985. Breakeven hauling distances for beef feedlot manure in southern Alberta. Can. J. Soil. Sci. 687-693.

10. Gilley, J.E., B. Eghball, J.M. Blumenthal and D.D. Baltensperger. 1999. Runoff and erosion from interrill area as affected by the application of manure. T. Am. Soc. Agr. Eng. 42:975-980.

11. Haan, C.T., B.J. Barfield and J.C. Hayes. 1994. Design Hydrology and Sedimentology for Small Catchments. Academic Press, p. 38-101.

12. Hubbard, R.K., D.L. Thomas, R.A. Leonard and J.L. Butler. 1987. Surface and shallow ground water quality as affected by centre pivot applied dairy cattle wastes. Transactions ASAE. 30:430437.

13. Jarvis, S.C., M. Sherwood and J.H.A.M. Steenvoorden. 1987. Nitrogen losses from animal manures: from grazed pastures and from applie dslurry. In Animal Manure on Grassland and Fodder Crops, ed. H.G. van der Meer, R.J. Unwin, T.A. van Dijk and G.C. Ennik. Martinus Nijhoff, Dordrecht, NL, pp. 195-212.

14. Lazcano, C., M. Gómez-Brandón and J. Domínguez. 2008. Comparison of the effectiveness of composting and vermicomposting for the biological stabilization of cattle manure. Chemosphere 72(7): 1013-1019.

15. Leon-Gonzlez, F., M.M. Hernndez-Serrano, J.D. 
Etchevers, F. Payn-Zelaya and V. Ordaz-Chaparro. 2000. Short-term effect on macro aggregation in a sandy soil under low rainfall in the Valley of Mexico. Soil Till. Res. 56:213-217.

16. Lithourgidis, A.S., T. Matsib, N. Barbayiannisb and C.A. Dordasc. 2007. Effect of Liquid Cattle Manure on Corn Yield, Composition, and Soil Properties. Agron. J. 99:1041-1047.

17. Long, F.N.J. and H.I. Gracey. 1990. Effect of fertilizer nitrogen source and CS on herbage production in nitrogen utilization. Grass Forage Sci. 45:431-442.

18. Matsi, T., A.S. Lithourgidis and A.A. Gagianas. 2003. Effects of injected liquid cattle manure on growth and yield of winter wheat and soil characteristics. Agron. J. 95:592-596.

19. Miller, J.J., E.C. Olson, D.S. Chanasyk, B.W. Beasley, F.J. Larney and B.M. Olson. 2006. Phosphorus and nitrogen in rainfall simulation runoff after fresh and composted beef cattle manure application. J. Environ. Qual. 35:1279-90.

20. Newton, G.L., J.K. Bernard, R.K. Hubbard, J.R. Allson, R.R. Lowrance, G.J. Gascho, R.N. Gates and G. Vellidis. 2003. Managing manure nutrients through multi-crop forage production. J. Dairy Sci. $86: 2243-2252$

21. Nyamangara J., J. Gotosa and S.E. Mpofu. 2001. Cattle manure effects on structural stability and water retention capacity of a granitic sandy soil in Zimbabwe. Soil Tillage Res. 62:157-162.

22. Owens, L.B., W.M. Edwards and R.W. Van Keuren. 1984. Peak nitrate-nitrogen values in surface from fertilized pastures. J. Environ. Qual., 13:310-312.

23. Phillips, P.A., J.L.B. Culley, F.R. Hore and N.K. Patni. 1981. Pollution potential and corn yields from selected rates and timing of liquid manure applications. Trans. ASAE 24:139-144.

24. Ramos, M.C., J.N. Quinton and S.F. Tyrrel. 2006. Effects of cattle manure on erosion rates and runoff water pollution by faecal coliforms. J. Environ. Manage. 78:97-101.

25. Sherwood, M. and A. Fannin., 1981. Nutrient content of surface water from land treated with animal wastes. In: Brogan, J.C. (Ed.), Nitrogen Losses and Surface Runofffrom Land Spreading of Manures. Martinus Nijhoff W. Junk, The Hague, pp. 5-17.

26. Smith, K.A., D.R. Jackson and P.J. Withers. 2001a. Nutrient losses by surface following the application of organic manures to arable land. 2. Phosphorus. Environ. Pollut. 112:53-60.

27. Smith, K.A., D.R. Jackson and T.J. Pepper. $2001 \mathrm{~b}$. Nutrient losses by surface following the application of organic manures to arable land. 1. Nitrogen. Environ. Pollut. 112:41-51.

28. Sommerfeldt, T.G., C. Chang and T. Entz. 1988. Long-term annual manure applications increase carbon to nitrogen ratio. Soil. Sci. Am. J. 52: 1667-1672.

29. Sonneveld, M.P.W., J.J. Schröder, J.A. de Vos, G.J. Monteny, J. Mosquera, J.M.G. Hol, E.A. Lantinga, F.P.M. Verhoeven and J. Bouma. 2008. A Whole-Farm Strategy to Reduce Environmental Impacts of Nitrogen. J. Environ. Qual. 37:186195.

30. Steffens, G. 1991. Odor and ammonia release during and after application of livestock manure. Dtsch Tierarztl Wochenschr. 98:261-264.

31. Vadas, P.A., W.J. Gburek, A.N. Sharpley, P.J.A. Kleinman, P.A. Moore Jr., M.L. Cabrera and R.D. Harmel. 2007. A Model for Phosphorus Transformation and Runoff Loss for Surface-Applied Manures. J. Environ. Qual. 36:324-332.

32. VanWieringen, L.M., J.H. Harrison, T. Nennich, D.L. Davidson, L. Morgan, S. Chen, M. Bueler, and F. Hoisington. 2005. Manure Management Effects on Grass Production, Nutritive Content, and Soil Nitrogen for a Grass Silage-Based Dairy Farm. J. Environ. Qual. 34:164-173. 
Jung et al.: Productivity of Corn and Nutrient Run-off in the Slopes

33. Wenchuan, Q., M. Dickman and W. Sumin. 2001. (접수일: 2011년 3월 14일, 수정일 1차: 2011년 4월 Multivariate Analysis of Heavy Metal and Nutrient 5일, 수정일 2차: 2011년 4월 15일, 게재확정일: Concentrations in Sediments of Taihu Lake, 2011년 6월 24일)

China. Hydrobiologia 450:83-89. 